\title{
ANALYSIS OF PRODUCT QUALITY AGAINST DECISION OF PURCHASING KERUPUK HALAL IN CIAMIS DISTRICT
}

\author{
Fitrnaty Adirestuty \\ Institut Agama Islam Darussalam (IAID) Ciamis-Jawa Barat \\ Email: fitranty.adirestuty@iaid.ac.id \\ Ika Dartika \\ Institut Agama Islam Darussalam (IAID) Ciamis-Jawa Barat \\ Tsania Salsabila \\ Institut Agama Islam Darussalam (IAID) Ciamis-Jawa Barat
}

\begin{abstract}
Halal "kerupuk" are one of the snacks that are in demand by all people. In order to maintain the stability of cracker sales, the company strives to maintain the quality of halal kerupuk. In fact, currently found many cracker products whose quality is considered poor by consumers. This study aims to determine the effect of product quality on increasing the sales volume of halal kerupuk in Cijeungjing District, Ciamis Regency. This type of research is quantitative research using correlational research methods, which is a method used to determine the magnitude of the relationship between variables. Data collection techniques using questionnaires, documentation studies, and observations. Data analysis used simple regression analysis. The results of data analysis showed that there was an effect of product quality on sales of halal fertilizers in Cijeungjing District, Ciamis Regency.
\end{abstract}

\begin{abstract}
Abstrak
"Kerupuk" halal merupakan salah satu jajanan yang diminati oleh semua kalangan. Guna menjaga kestabilan penjualan kerupuk, perusahaan berupaya untuk menjaga kualitas kerupuk halal. Pada kenyataannya, saat ini ditermukan banyak produk kerupuk yang kualitasnya dinilai kurang baik oleh konsumen. Penelitian ini bertujuan untuk mengetahui pengaruh kualitas produk terhadap peningkatan volume penjualan kerupuk halal di Kecamatan Cijeungjing Kabupaten Ciamis. Jenis penelitian ini adalah penelitian kuantitatif dengan menggunakan metode penelitian korelasional, yaitu suatu metode yang digunakan untuk mengetahui besarnya hubungan antarvariabel. Teknik pengumpulan data menggunakan angket, studi dokumentasi, dan observasi. Analisis data menggunakan analisis regresi sederhana. Hasil analisis data menunjukkan bahwa terdapat pengaruh kualitas produk terhadap penjualan kepupuk halal di Kecamatan Cijeungjing Kabupaten Ciamis.
\end{abstract}

Keywords: Kerupuk, Halal, Product Quality, Sales

\section{Introduction}

Product quality is the determinant factor of the level of satisfaction that consumers get after making a purchase and use of a product and will affect consumers to make repurchase or not, so business managers are required to create a product 
tailored to the needs or tastes of consumers. Consumer perceptions of product quality can be affected by product price. Consumers have the perception, if the higher the price of a product the higher the quality of the product. Consumers can have such perceptions when they have no guidance or other reference to the quality of the product, other than the price of the product. But actually the quality of a product can be influenced also by the reputation of the store, advertising, and others.

Ideal crackers is one of the snacks are quite enthused by all circles and crackers this dream has been found in many markets. In this study, the ideal cracker product was developed as a new product innovation. Judging from the target of the quality of the product is intended for all circles from children to parents, because this product is a snack crackers are quite famous snacks among the community, it needs a good quality analysis effect for ideal cracker products can be accepted more widely by the community. Ideal cracker products have the advantage of other products that contain lots of protein for the prevention of osteoporosis. In addition, the raw materials used are also easy to find. Ideal cracker products are safe for consumption by the community because used materials of good quality and have a good nutritional content. In the ideal product of cracker product indicator is the totality of features that affect the appearance, taste, shape, packaging, price and product quality based on customer needs while the indicators contained in the sales are: promotion, service, delivery, payment.

The sales concept assumes that consumers typically show weak buying desires or denials and need to be persuaded or treated with courtesy and patience to make them more willing to buy the product. Therefore, the company should conduct a series of effective sales activities and provide promotional tools to make the amendment more enhanced. Most companies practice the sales concept if they have excess capacity. Their immediate goal is to sell what they can make instead of making something new that can be sold. In the modern industrial economy, production capacity is built in such a way that most markets are buyers' (ie dominant buying) markets and sellers have to work hard to reach buyers.

From the monitoring can be in the know sales of crackers dreams. For that researcher make table cracker sale of dream last three month that is month of October, November and December 2016.

Based on the sales table for the period of October 2016 until December 2016, it is unstable or can be said to decrease so significantly every month. In October November sales decreased sales in a row that is equal to Rp. 480,000 and in November - December 2016 experienced a fairly stable sales increase of Rp. 122.895.000.

This research is done because the researcher is interested to know about the effect of product quality to the sale of dream crackers. However, this study is similar to the research conducted by Bekti setiawati who conducted research at State University of Semarang which resulted in the influence of product quality by $31.6 \%$. For hypothesis proposed in this research is there is influence of product quality to sale of cracker dreams in District Cijeungjing Regency of Ciamis.

\section{Theoritical Review}

\section{Understanding Product Quality}

Product quality is an understanding that the product offered by the seller has more selling value that is not owned by a competitor's product. Therefore the company 
tries to focus on product quality and compare it with the products offered by the competitor companies. However, a product with the best performance or even a better look is not the highest quality product if it is not what the market wants and wants. According to Kotler and Armstrong (2004: 283) the meaning of product quality is "the ability of a product to perform its functions, it includes the product's overall durability, reliability, precision, ease of operation and repair, and other valued attributes" a product in demonstrating its function, it includes overall durability, reliability, accuracy, ease of operation and product reparation as well as other product attributes. Product quality is the ability of a product to perform its functions include, reliability, accuracy of ease of operation and improvement, and other valuable attributes. To improve the product quality the company can implement the program "Total Quality Management (TQM)". In addition to reducing product damage, the ultimate goal of Total Quality Management (TQM) is to increase customer value. In this research, the quality of the product and its purchase decision is the durability of cracker crispness and the distinctive flavor of the dream crackers (Sallis, 2008). Allah SWT has made the criteria of food that can be consumed with the standard thayiban haliti. Including halalan here means the type of food that is allowed to be consumed and not forbidden. While including thayyiban means all types of foods that provide human benefits because it has met health requirements (eg nutrition, protein, etc.) is not unclean, not intoxicating, does not bring negative effects to physical and psychological health, and obtained in a lawful way. Allah says in Surah Al-Baqarah, (2): 168, as follows:

$$
\text { يآ يها الناس كلو امما فى الارض حلالا طيبا العربية }
$$

Say: "Men of all, eat what is lawful again from what is on the earth, and do not follow the steps of shaitan, for verily Satan is a clear enemy to you. (Q.S. Al-Baqarah, 2: 168)

The above verse is the advice of Allah SWT. To humans to always choose a kosher food both in meeting the needs of his life and not follow the trail of shaitan who just follow the lust. Thus, all kinds of food and beverages are legally mubah and lawful, except when there is information that forbid it. Allah SWT has instructed us to eat halal and good food. The word halal and good is closely related to human health, because it can be kosher food but not good for someone (health) or vice versa.

Quality reflects all dimensions of product offerings that generate customer benefits. The quality of a good product in the form of goods or services is determined through dimensions (Tjiptono, 2008: 54). Product quality dimensions consist of: Performance, Durability, Conformance to specifications, Features, Reliabilty (reliability), Aesthetics (aesthetic), Perceived quality (Impression quality), Based on dimensions -dimensi above, it can be concluded that a quality dimension is a requirement for a value of the product allows to be able to satisfy customers as expected (Mullins, 2005: 422).

Consumer behavior is a process that is closely related to the purchase process, at that time consumers perform activities such as i search, research, and evaluate the product. Consumer behavior are the things that underlie consumers to make purchasing decisions. Included in the consumer's behavior in addition to the quality of the product as well as the price of the product or service. If the price of a product is not too high, then consumers will not take too long to think and conduct consumer behavior activities. However, if the price of a good or service can be considered high, or 
expensive, then the consumer will give more effort to the goods. The buyer will take longer to perform consumer behavior, such as viewing, asking, evaluating, and considering. According to Anoraga (2004: 223), consumer behavior is the behavior shown through the searching, purchasing, use, evaluation and determination of products or services that they hope can satisfy their needs. Consumers have an interesting diversity to learn because it covers all individuals of different ages, cultural backgrounds, education, and other socioeconomic circumstances. Therefore, it is important to learn how consumers behave and what factors influence the behavior. The significance of consumer behavior is physical activity, all of which involve individuals in assessing, obtaining and using goods and services economically. Individuals who make purchases to meet their personal needs and household consumption can be termed end customers. But that does not mean other people are not involved in the purchase process, however many people will be involved in buying the product. Where each person is involved and has their own role (Kotler and Susanto, 1999: 246).

\section{The Concept of Sales}

Sales is a transaction activity performed by 2 (two) or more parties by using a valid payment instrument. Sales is also one source of income a person or a company that performs transactions selling and buying products in a company if the greater the sales the greater the income earned by a person or company. According to Swastha (2001: 1) Sales is the science and art of personal influences made by the seller to invite others to be willing to buy goods and services offered. Where, Sales is one of the marketing functions, in order for the company to earn profits to keep the company's operational activities running and sales are also part of promotion and promotion is one part of the overall marketing system. Meanwhile, Sales by Winardi (2005: 26) Sales is the gathering of a buyer and seller with the aim of exchanging goods and services based on valuable considerations such as money considerations. In the sales process, the seller or provider of goods and services assigns a commodity to the buyer for a specified price. Sales can be done through various methods, such as direct sales, and through sales agents.

The strict teaching of Islamic law to avoid the things that are forbidden by Allah and to carry out what is ordered to make the Muslim consumer is not an easily tempted consumer in his consumption pattern. They are limited by the divinity and to the haram that is contained in the texts of the Qur'an and Al-Hadith which became their primary guide. Increasing understanding of religion increasingly makes Muslim consumers become increasingly selective in the selection of consumed products. Especially in Indonesia, Muslim consumers are protected by institutions that specifically task to audit products consumed by Muslim consumers in Indonesia. This institution is the Institute for Supervision and Distribution of Drugs and Foods Indonesian Ulema Council (LPPOM-MUI) is based on the Halal Product Guarantee Act. 33 of 2013. This institution oversees the products circulating in the community by providing halal certification so that products that have halal certificate can label halal on its products. This means that the product is processed and its contents have passed examined and free from the elements that are prohibited by Islamic religious teachings, or the product has become the category of halal products and does not contain haram and can be consumed safely by Muslim consumers. The existence of LPPOM-MUI can help the community facilitate the process of halal inspection of a product. By registering the product to be audited for its halal validity by LPPOM-MUI so that its 
products can attribute the halal label and that means the product has been halal for Muslim consumption and loss of value limiting the product with Muslim consumer. With this halal label Muslim consumers can ensure which products are bol eh their consumption, ie products that have and include halal label on the packaging.

Factors influencing sales activities according to Swastha (2003: 406) in his book Modern Marketing Management namely: Conditions and Ability Seller where the seller must be convinced to the buyer, in order to successfully achieve the expected sales goals such as types and characteristics on offer such goods, food, etc., then the price of the product, terms of sale such as payment, warranty and so on, Market conditions ie the market as a group of buyers or parties who are targeted in sales, may also affect sales activities, usually a sales issue is handled by a separate section (sales department) held by certain people or experts in sales. Another case with small companies, where sales problems are handled by people who also perform other functions this is because the number of workers a little, the organizational system is simpler, the problems faced, as well as the means it has not big companies, Other factors such as advertising, demonstrations, campaigns, gift giving, often affect sales. There are entrepreneurs who hold on to one principle that it is most important to make good goods. When the principle is implemented it is expected that the buyer will buy again the same item. Therefore, the company made efforts to buyers interested in their products.

\section{Methods}

The method used in this research correlational research method, which is a method used to determine the magnitude of relationships between variables (Kasmadi \& Sunariah, 2013: 64). Sources of data obtained from the student population of 300 people and sampled by $10 \%$. So that the research sample amounted to 30 people namely the ideal crackers consumers in Ciamis who work as traders, so the data source is taken primary data source. This research uses quantitative research type that is quantitative research is a process of finding knowledge using numerical data as a tool to analyze information about what want to know (Sujarweni, 2012: 39).

The instruments used were questionnaires, documentation, and observation. The validity of data obtained by the existence of primary data which is the main data source obtained from the questionnaire that has been distributed to 30 respondents that is the ideal crackers in ciamis who work as a trader. Data analysis using descriptive analysis using SPSS version 20.0 For Windows.

The test requirements analysis are: 1) normality test. In addition to the hypothesis test analysis obtained from: 1) Pearson correlation test, 2) simple linear regression analysis, 3) linearity test, 4) t test. All testing using SPSS version 20.0 For Windows.

\section{Results and Discussion}

Results from the research that has been done with the number of respondents 30 people. Obtained in descriptive statistics of variable $\mathrm{X}$ (product quality) with mean value (Mean) 41,80 and Standard Deviation 4,859 with normality of data with value of signifikansi $0,016>0,05$. So it can be concluded that the data in the test is a normal distribution. Meanwhile, for variable $\mathrm{Y}$ (sales) obtained in descriptive statistic with 
mean value (Mean) 42,47, with Standard Deviation 3,821. Thus, it shows that the data in the test is normally distributed. In addition, the results of the normality test using the Kolmogorov-Smirnov Test of Normality were obtained with a significance value of product quality variables of 0.016 and sales of $0.134>0.05$ stating that the two variables are normally distributed.

Based by count, it can be seen that product quality variables have the highest value (maximum) 59 and the lowest value (minimum) 33, so the average value (mean) is 41.80 . The difference between the highest value and the lowest value (range) is 26 , the median value of the median set of data is 40.00 with the standard deviation of 4.859 .

Based on the above table, it can be seen that sales variables have the highest value (maximum) 50 and the lowest value (minimum) 34, so the average value (mean) is 42.47. The difference between the highest value and the lowest value (range) is 16, the median value of the median set of data is 42.00 with the standard deviation of 3.821 and the other data in the table.

There are pengauh quality products to the sale of Idaman crackers in District Cijeungjing Ciamis regency. Based on the result above sig value. (2-tailed) of 0.001 as a decision-making it can be concluded there is a significant relationship between product quality with sales. This is because $0.001<0.05$ there is a significant correlation between variable $\mathrm{X}$ (Product quality) with variable Y (Sales).

From the analysis the authors obtained the correlation coefficient between variables $\mathrm{X}$ with $\mathrm{Y}$ variable of 0.573 greater than 0.05 . Then Ho accepted and correlation coefficient of 0.573 is pertained to the interpretation of moderate correlation, because it is in the range 0.41-0.60.

Based on the statistical data processing with SPSS, to determine the contribution of independent variable to the dependent variable, it can be known with $\mathrm{R}$ Square 0,329 means that the variable $\mathrm{X}$ affects the $\mathrm{Y}$ variable of $32.9 \%$.

Influence between variable $\mathrm{X}$ to variable $\mathrm{Y}$ equal to $32,9 \%$. This shows that the influence between variable $\mathrm{X}$ to variable $\mathrm{Y}$ is in low correlation qualification is in the range 0.20-0.399 and there is still the influence of other variables of $67.1 \%$ to variable $Y$ in addition to variable $\mathrm{X}$.

The result of the research that has been clearly described above, that the hypothesis on the basis of the lifted from the theories used mentioned that the quality of the product has a positive and significant (real) effect on the sales of the ideal crackers in the district cijeungjing district ciamis. So, if the product is guaranteed quality well then the sales idamanpun crackers high. On the contrary, if the product is not guaranteed to be of good quality then the selling level of idamanpun crackers will tend to be low or less. This happens because the quality of the product is one of the decisive factors that affect the sale of these products.

\section{Conclusion}

The influence of product quality at the ideal cracker company in Cijeungjing subdistrict of ciamis district reaches $95 \%$. This shows that the quality of the ideal cracker product is in very good qualification. For, the ideal cracker sales in District Cijeungjing Ciamis Regency also reached 95\%. This shows that the sale of ideal crackers is in very good qualification. Therefore, to see the magnitude of the effect of variable $\mathrm{X}$ to $\mathrm{Y}$ correlation test techniques used to use parametric correlation (Product Moment 
Pearson Correlation Test). From the calculation using the correlation test of 0.573 (medium correlation). To prove the significance of correlation coefficient is done by using $t$ test and obtained value of significance $0.001<0.05$. So Ho decision in rejected and Ha received. This means that the variable $\mathrm{X}$ affects the $\mathrm{Y}$ variable of $32.9 \%$ with a low correlation interpretation is in the range 0.20-0.399. The above results state that there is a significant influence between product quality and sales.

\section{REFERENCES}

Kasmadi \& Sunariah. (2013). The Modern Guide for Quantitative Research. Bandung: Alfabeta.

Sugiyono. (2012). Combined Research Methods (Mixed Methods). Bandung: Alfabeta. Sujarweni. (2012). Research methodology. Yogyakarta: New Library Press.

Bekti Setiawati. 2006. Research The Effect of Product Quality and Promotion on Pupil Rambak Purchasing Decision "DWIYONO" in Penanggulan Village Kec. Pegandon Kab. Kendal. Semarang. It: 30 - 41.

Kasmadi \& Sunariah. (2013). The Modern Guide for Quantitative Research. Bandung: Alfabeta.

Kotler \& Armstrong. 2001. Principles of Marketing. Jakarta: Erland.

Swastha. 2001. Modern Marketing Management. Yogyakarta: BPFE.

Winardi. 2005. Change Management (The Management of Change). 1st Print, Jakarta: Prenada Media. 
